RHODORA, Vol. 118, No. 974, pp. 206-226, 2016

CCopyright 2016 by the New England Botanical Club

doi: 10.3119/15-23; first published on-line May 2, 2016.

\title{
LIMESTONE FLORA OF THE SIMONTON CORNER QUARRY PRESERVE, ROCKPORT, MAINE, USA
}

\author{
Margaret Stern \\ College of the Atlantic, 105 Eden Street, Bar Harbor, ME 04609 \\ Current address: P.O. Box 272, Talkeetna, AK 99676
}

\section{Ian D. Medeiros ${ }^{1}$}

College of the Atlantic, 105 Eden Street, Bar Harbor, ME 04609

${ }^{1}$ Author for Correspondence; e-mail: imedeiros@coa.edu

\section{LuKa NegOITA}

Department of Biology, Syracuse University, 114 Life Sciences Complex, Syracuse, NY 13244

\section{Nishanta RaJAKARUNA}

College of the Atlantic, 105 Eden Street, Bar Harbor, ME 04609; Unit for Environmental Sciences and Management, North-West University, Private Bag X6001, Potchefstroom, 2520, South Africa

ABSTRACT. Limestone is a distinctive substrate that has significant effects on soils and plants. The present study characterizes the diversity of vascular plants, bryophytes, and lichens at the Simonton Corner Quarry Preserve, an abandoned limestone quarry in Rockport, Maine, USA, which was in operation in the late $1800 \mathrm{~s}$. We document vascular plant diversity and associated edaphic features (i.e., soil $\mathrm{pH}$ and elemental chemistry) using 30 $5 \times 5$ meter plots spread throughout the site. For vascular plants, 114 species in 96 genera and 50 families were observed; few of these species are known to prefer calcareous environments, and 38\% are nonnative. Conversely, the soiland rock-dwelling cryptogam biota, which comprises 21 moss species in 13 families and eight lichen species in three families, contains many calciphilic species. The bryoflora conspicuously lacks liverworts, whereas the lichen biota is dominated by cyanolichens. This study will inform future conservation and reclamation work at this and other human-altered limestone sites in Maine and floristically similar areas and contribute to our understanding of the geoecology of New England.

Key Words: bryophytes, carbonate floras, edaphic factor, geobotany, lichens, limestone, plant-soil relations

Plants are highly influenced by the substrates in which they grow: Soil chemistry, texture, and structure all contribute to an overall "edaphic factor" that has important effects on individual plant species and the composition of plant communities (Rajakaruna and Boyd 
2008). Special soil types - chemically distinctive and azonal soilsoften harbor high numbers of rare and endemic species because they are inhospitable to competing species (O'Dell and Rajakaruna 2011) or because the strong selective pressures they impose contribute to rapid speciation (Kay et al. 2011; Rajakaruna 2004). Soils derived from limestone represent one of these special substrates; limestone was the first of the "special soils" to be recognized as floristically distinct and has received extensive study throughout the world (Kruckeberg 2002).

Biologists have long known that limestone-derived soils support particular calcicolous plants (Kruckeberg 2002), and as a consequence New England's early botanists frequently visited limestone sites during their collecting excursions (e.g., Fernald and Wiegand 1910; Long 1921). However, these botanists generally focused on the most unique plants at the outcrops they visited, so there have been only a few comprehensive botanical surveys of limestone substrates in the northeastern United States (but see Bailey et al. 2015 for a recent study of a limestone-influenced site in eastern Canada). The vegetation of limestone outcrops has received more attention in the southeastern United States (e.g., Baskin and Baskin 2004; Baskin et al. 2007; Cipollini et al. 2013; Crow and Ware 2009; Hill 1992; Lawless et al. 2006), where the lack of a recent glacial history (Dyke et al. 2002) and absence of acidic conifer-dominated forests allow limestone outcrops to exert a greater influence on soils and thereby harbor rare and endemic species and demonstrate a particular edaphic climax (Baskin et al. 2004). Nevertheless, limestone habitats are known to host a number of New England's rare plants (Brumback and Gerke 2013; Haines 2011).

Limestone (calcium carbonate; $\mathrm{CaCO}_{3}$ ) affects soils and plants in at least two distinct ways - $\mathrm{pH}$ and calcium content (Lee 1998), although the causes of calciphily and calcifugy have yet to be completely elucidated. Calcium is an essential nutrient required for structural and signaling processes within the plant cell (Hepler 2005; White and Broadley 2003). Differences between plants with regard to calcium requirements are likely an important part of the calciphile/calcifuge story (Lee 1998). The elevated $\mathrm{pH}$ of limestone-derived soils is the other key element of the limestone "edaphic factor." The availability of plant nutrients - and toxic heavy metals - varies with $\mathrm{pH}$ (Tyler and Olsson 2001), and species-specific requirements and tolerances help to determine which plants can live on limestone substrates. The elevated $\mathrm{pH}$ of calcareous soils also increases cation exchange capacity and organic matter turnover (Brady and Weil 1996). Calcicolous bryophytes (e.g., Hattaway 1980) and lichens (e.g., Foote 1966; Gilbert et al. 1982; Yarranton and Green 1966) are also important elements of the 
biota of calcareous habitats; limestone often supports the most distinctive cryptogam biota of any rock type in a region (e.g., Bates 1978). For bryophytes, calcium concentration appears to be less important than $\mathrm{pH}$ (Bates 2008 and references cited therein), pointing to element availability as a probable cause of bryophyte calciphily.

Although most floristic and ecological research on limestone has focused on areas that have experienced minimal human interference, sites that have undergone anthropogenic changes are also worthy of study. Abandoned quarries and mines can harbor unique vegetation (Hodgson 1982; Mansfield et al. 2014). Limestone quarries have been shown to serve not only as habitats for unique plant species (because quarrying exposes bedrock, the biological impact of which would otherwise be masked by soil) but also as refugia for wildlife, often as a result of their distinct plant communities (Davis 1979). Research on highly disturbed and human-influenced sites includes many studies of abandoned limestone and chalk quarries in Great Britain (e.g., Davis 1976, 1979, 1982; Davis et al. 1985; Humphries 1977; Johnson et al. 1978; Usher 1978; Wheater and Cullen 1997), Tennessee (Thompson and McKinney 2006), Kentucky (Thompson and Green 2010; Thompson et al. 2005), and Ohio (Reinking 1979; Ross 1970). The unique nature of chalk and lime quarries has been recognized in Britain for hundreds of years, beginning with the first flora of Britain (Ray 1660), which includes a list of botanically significant plants found at a chalk pit near Cambridge.

Because they may harbor rare species, and because resource extraction has affected large areas of land, quarries have developed a reputation as interesting sites for conservation and restoration projects (Catchpole and Tydeman 1975; Department of Environment 1976; Johnson et al. 1978; O'Dell and Claassen 2009; Ratcliffe 1974; Tropek et al. 2010). Revegetation of disturbed landscapes - particularly with native, edaphically adapted plants - can reduce the environmental impacts of mining and quarrying (O'Dell and Claassen 2009; O'Dell 2014).

Despite prolonged interest in disused limestone quarries of the British Isles, very few complete floristic inventories of humaninfluenced limestone habitats have been published in the United States (Thompson and Green 2010). To date, there are no published studies characterizing the entire flora of a quarried limestone outcrop in Maine, despite the presence of limestone in the region. In this paper, we present a floristic inventory and description of soil and rock chemistry of the Simonton Corner Quarry Preserve (hereafter referred to as the Quarry, Preserve, or SCQP) in Rockport, Knox County, Maine. Our 


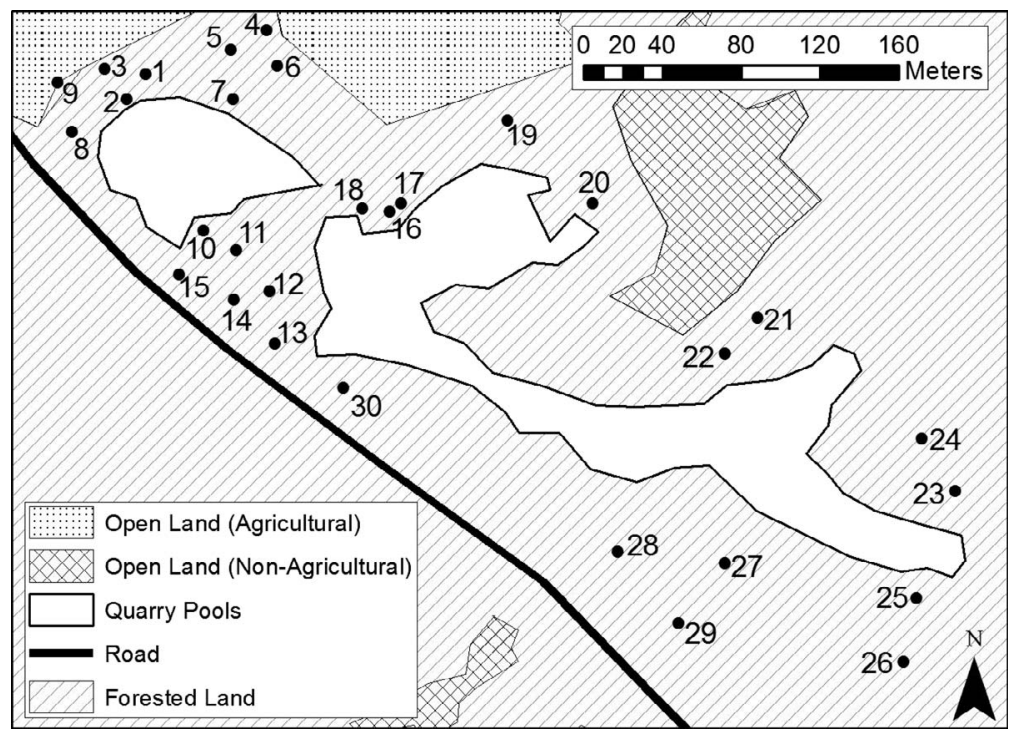

Figure 1. Simonton Corner Quarry Preserve, Rockport, Knox County, Maine $\left(44^{\circ} 11^{\prime} 57.91^{\prime \prime} \mathrm{N}, 69^{\circ} 6^{\prime} 23.44^{\prime \prime} \mathrm{W}\right)$. Numbered points are vegetation survey plots.

survey will add to the limited information available on the flora of disturbed limestone habitats in the northeastern United States.

\section{MATERIALS AND METHODS}

Site description. The Simonton Corner Quarry Preserve is an abandoned limestone quarry in Rockport, Knox County, Maine, USA $\left(44^{\circ} 11^{\prime} 57.91^{\prime \prime} \mathrm{N}, 69^{\circ} 6^{\prime} 23.44^{\prime \prime} \mathrm{W}\right.$; Figure 1). When we conducted our fieldwork, the Preserve was owned by the Nature Conservancy and maintained by the Coastal Mountains Land Trust (www. coastalmountains.org), an organization headquartered in nearby Camden, Maine. Ownership of the preserve was subsequently transferred to the Coastal Mountains Land Trust. Little information is available on the history of this particular quarry; for the purposes of our study we presume that the quarry followed the same patterns of occupation and abandonment as other quarries in the region, described below. For comprehensive coverage of limestone quarrying in this region, see Grindle (1971).

The limestone quarries in the vicinity of Rockland, Maine, were once the principal source of limestone for New England (Finch and Howe 
1930; MacLachlan et al. 2006). This area supplied the lime used in cement and plaster in the northeast from the late 1800s through the late 1950s, by which time the majority of the high-grade lime rock had been mined to extinction (MacLachlan et. al. 2006). The Rockland Formation, a 12-mile vein of lime rock in Knox County, is Cambrian or Ordovician in origin and comprises the Weskeag quartzite, siliceous limestone, and Rockport limestone (MacLachlan et al. 2006). Rockport limestone makes up the majority of the Rockland Formation (Bastin 1908). Today only one limestone quarry in this region remains in operation: the Dragon Cement Company quarry in Thomaston, Maine (MacLachlan et al. 2006).

Quarrying of the present-day SCQP occurred for a little over a decade during the mid-1880s to mid-1890s (MacLachlan et al. 2006; Robinson 1907). After limestone extraction in the area ceased, the site was (and to a certain extent continues to be) used as a trash dump by Camden area residents (anonymous local resident, pers. comm.). Later on, as the quarry pits filled with water, the ponds were stocked with fish and the pools were used as fishing and swimming holes by locals (anonymous local resident, pers. comm.). The preserve presently receives minimal use, and is sometimes accessed by locals walking their dogs and used as an illegal dumpsite and fishing hole (M. S., pers. obs.). Although the Preserve includes land beyond the quarry pits, for the purposes of this study we focused only on the area around the quarry pools.

Floristic survey. To quantitatively sample the floristic diversity of the Preserve, $305 \times 5$ meter plots were placed haphazardly along eight transects radiating outward from the quarry pools and extending to the boundary of the Preserve (Figure 1). Each of these plots was further divided into $1 \times 1$ meter subplots to facilitate the estimation of percent cover. For each plot, vascular plant taxa were recorded and percent cover estimated (canopy cover was not included in these estimations). A comprehensive checklist of plants on site, including those species not found in the plots, was generated by collecting plants while walking the transects between plots and walking the trail around the pools. Vascular plant species were identified using Haines (2011). Species not identified in the field have been vouchered at HCOA.

Bryophytes and lichens were collected during one visit in September 2012 (when specimens were taken solely from the $305 \times 5$ meter plots) and another in May 2014 (when specimens were collected during a walk throughout the property). Lichens were identified with Hinds and Hinds (2007); bryophytes were identified using Allen $(2005,2014)$ and 
Ireland and Bellolio-Trucco (1987). All lichen and bryophyte specimens have been vouchered at HCOA.

Soil analysis. Soil was collected from each of the $305 \times 5$ meter plots. At the center and four corners of each plot, litter and duff were brushed away with a trowel and the upper 5-10 $\mathrm{cm}$ of underlying soil were collected and mixed. Composite samples were placed in plastic Ziploc bags and air-dried for two weeks. Bags were then closed and stored in a dark cabinet prior to testing. Soil testing was conducted by the Soil Analytical Lab at the University of Maine, Orono. Soil pH was measured in distilled water and $0.01 \mathrm{M} \mathrm{CaCl}$. Organic matter was measured by loss on ignition (LOI) at $375^{\circ} \mathrm{C}$. We extracted $\mathrm{NO}_{3}$ and $\mathrm{NH}_{4}{ }^{+}$in $\mathrm{KCl}$ solution. Other elements (Ca, K, Mg, Na, P, Al, B, Cu, $\mathrm{Fe}, \mathrm{Mn}, \mathrm{S}, \mathrm{Zn}, \mathrm{Cd}, \mathrm{Cr}, \mathrm{Ni}$, and $\mathrm{Pb}$ ) were extracted in ammonium acetate $\mathrm{pH} 4.8$ in a modified Morgan extract and $\mathrm{P}, \mathrm{NO}_{3}$, and $\mathrm{NH}_{4}{ }^{+}$ were determined colorimetrically with an Alpkem A/E ion analyzer (OI Analytical, College Station, TX); all other elements were determined by ICP-OES (Thermo Scientific, Tewksbury, MA). Total water-soluble salts were measured by electrical conductivity (EC) in a saturated media water extraction. Effective cation exchange capacity was calculated by summation of milliequivalent levels of $\mathrm{Ca}, \mathrm{K}, \mathrm{Mg}$, and $\mathrm{Na}$.

Rock analysis. Three rock samples were collected from around each of the two quarry pits for elemental analysis by X-ray fluorescence (XRF). The three separate samples from each pit were combined prior to analysis (i.e., two composite samples were analyzed). Rock elemental analyses were carried out by the GeoAnalytical Lab at Washington State University (Pullman, WA). Samples were chipped and ground to a fine powder. The powder was weighed with di-lithium tetraborate flux at a 2:1 flux to rock ratio. Once weighed, the samples were mixed and then fused at $1000^{\circ} \mathrm{C}$ for 45 minutes in a muffle oven to produce a glass pellet. After cooling, the pellet was re-ground, re-fused, and polished on diamond laps. Major and minor elements were measured using an automated Thermo ARL Advant'XP+ wavelength dispersive sequential unit (Thermo Scientific, Tewksbury, MA). See Johnson et al. (1999) for a complete description of this process.

\section{RESULTS}

We documented a total of 114 species of vascular plants in 96 genera and 50 families at the SCQP (Appendix 1). Additionally, we identified 21 bryophyte species in 17 genera and 13 families (Appendix 2) and eight lichen species in three genera and three families (Appendix 3). No 
liverworts were found, although it is certainly possible that we missed some uncommon and inconspicuous species. The vegetation around the Quarry is predominantly forest, dominated by Fraxinus americana, Pinus strobus, Acer saccharum var. saccharum, and Quercus rubra. There is an extensive shrub understory, including Swida alternifolia, Prunus virginiana var. virginiana, Viburnum acerifolium, Toxicodendron radicans, and Prunus serotina var. serotina. The herbaceous understory was a minimal component of understory cover, but included Symphyotrichum lateriflorum, Hieracium piloselloides, Taraxacum officinale, Maianthemum canadense, and Galium mollugo as the most common species. Bryophytes, especially Thuidium delicatulum and Anomodon spp., covered a substantial portion of the forest floor. The lichens Scytinium lichenoides and Peltigera spp. were interspersed throughout the bryophyte vegetation.

Ten vascular plant species at the Preserve are considered invasive in New England (Berberis thunbergii, Frangula alnus, Hesperis matronalis, Rhamnus cathartica, Rosa multiflora, Poa compressa, Lonicera morrowii, Celastrus orbiculatus, Valeriana officinalis, and Lythrum salicaria), although of these species only $L$. salicaria is actually listed as invasive for Maine. Although not listed as invasive, Euphorbia cyparissias is a non-native species prohibited in Connecticut and Massachusetts (New England Wild Flower Society 2015). Forty-three (38\%) vascular plant species are considered non-native, with the remaining 71 taxa $(62 \%)$ considered native to New England. The most speciose families were Asteraceae (twenty-one species; 18\%), Rosaceae (9 species; $8 \%$ ), and Poaceae (8 species; 7\%). No new records for Maine were found, but Festuca trachyphylla may be a new report for Knox County (Kartesz and BONAP 2015).

Soil samples taken from the $305 \times 5$ meter plots (Table 1; Supplemental Data S1, available at https://nrajakaruna.files. wordpress.com/2015/11/supplemental-data.pdf) show a slightly acidic $\mathrm{pH}$ with a mean of $6.0 \pm 0.7(\mathrm{SD})$, higher than what is typically seen in Maine, and a high level of calcium. The $\mathrm{pH}$ of soil samples ranged from a low of 4.6 to a high of 7.2. Chemical analyses of rock samples (Table 1) indicate that the bedrock at SCQP has an elemental composition typical for limestone (Clarke and Washington 1924; Turekian and Wedepohl 1961).

\section{DISCUSSION}

Fernald and Wiegand (1910) did not find the limestone soils in the Rockland area to be botanically interesting, noting that "...the rock 
seemed very hard and the soil sterile as compared with the softer limestones and limy slates and the extremely fertile soil we had just seen in Aroostook County" (Fernald and Wiegand 1910: 119); we tend to concur with their general assessment, at least for vascular plants. The vascular plant survey of the SCQP revealed no species that are listed as threatened, rare, or endangered in Maine, and no native calcicoles. Nevertheless, it is important that limestone sites which do not host a characteristically calcareous vascular flora be documented in the scientific literature.

The vascular flora of the Preserve contains few calcicoles, likely as a consequence of the site's below-neutral $\mathrm{pH}$. The acidic $\mathrm{pH}$ at the Preserve may result from higher organic matter content in the soil or be an indication of the generally lower $\mathrm{pH}$ found in coastal forests in Maine. For example, at a serpentine outcrop on Little Deer Isle, Maine, average $\mathrm{pH}$ was 5.3 on exposed serpentine and 3.96 on forested serpentine (Pope et al. 2010), indicating that vegetation has a large influence on soil $\mathrm{pH}$. But the influence of bedrock is still quite important: The average $\mathrm{pH}$ values of granite-derived soils in the same study were 4.1 on exposed granite and 3.3 on forested granite.

We documented five pteridophyte species at the SCQP, none of which are listed as rare, endangered, or threatened in New England, and none of which are known to prefer calcareous habitats. This was somewhat surprising, considering the presence of rare and endemic pteridophyte species on limestone outcrops around the world (Baskin and Baskin 1974; He and Zhang 2010; Yesilyurt and Schneider 2010), including northeastern North America (Bailey 2013; Haines 2011; Kuehn and Leopold 1993).

A literature search indicated that a few plants on our species list do have some affinity for calcareous soils: Euphorbia cyparissias (Crompton et al. 1990), Gallium mollugo (Mersereau and DiTommaso 2003), and Epipactis helleborine (Brunton 1986; Webb and Scannell 1983). Curiously, these are non-native species in North America; they are all native to Europe. Two native species present at the site-Ostrya virginiana and Acer saccharum - have been reported to have some degree of preference for limestone soils over gneiss-derived soils (Balter and Loeb 1983), but are by no means calcicoles. And some species present at the SCQP are known to prefer "richer" soils. One of the nonnative species found at SCQP, Securigera varia, was previously reported as a noteworthy collection from limestone soils in the Rockland area (as Coronilla varia L.; Long 1921). No other taxa listed by Long (1921) were documented in the present study. 
Table 1. Average chemical features and elemental concentrations of soil and rock samples collected at the Simonton Corner Quarry Preserve. The soil column shows an average value and standard deviation for soil samples from the $305 \times 5 \mathrm{~m}$ plots. Soil elemental concentrations are reported as $\mathrm{ppm}(\mathrm{mg} / \mathrm{kg})$ in dry soil; other units are given in the table. Data for individual plots are available online as Supplemental Data S1. The rock column (Bedrock) shows the average values of the two rock samples. For bedrock, major element concentrations are indicated with *, and are given as \% weight of the mean rock samples; these values sum to $58.31 \%$ of rock weight. Other elements are reported as ppm; these trace elements account for only $0.03 \%$ of the rock weight.

\begin{tabular}{|c|c|c|}
\hline \multirow{3}{*}{$\begin{array}{l}\text { Chemical } \\
\text { Features } \\
\text { Measured }\end{array}$} & \multicolumn{2}{|c|}{ Elemental Concentrations } \\
\hline & Soil (mean) \pm & \\
\hline & SD ppm (mg/kg) & Bedrock \\
\hline $\mathrm{pH}-\mathrm{H}_{2} \mathrm{O}$ & $6.5 \pm 0.6$ & - \\
\hline $\mathrm{pH}-\mathrm{CaCl}_{2}$ & $6.0 \pm 0.7$ & - \\
\hline$\%$ LOI & $12.4 \pm 10.4$ & 41.36 \\
\hline $\mathrm{EC}(\mathrm{mmhos} / \mathrm{cm})$ & $0.34 \pm 0.21$ & - \\
\hline $\mathrm{NO}_{3}-\mathrm{N}$ & $26.3 \pm 47.6$ & - \\
\hline $\mathrm{NH}_{4}-\mathrm{N}$ & $3.7 \pm 4.7$ & - \\
\hline $\mathrm{Ca}$ & $5589 \pm 5417$ & $47.73^{*}$ \\
\hline $\mathrm{K}$ & $127 \pm 45$ & $0.22 *$ \\
\hline $\mathrm{Mg}$ & $243 \pm 114$ & $4.87^{*}$ \\
\hline $\mathrm{Na}$ & $18 \pm 6$ & $0^{*}$ \\
\hline ECEC $(\mathrm{meq} / 100 \mathrm{~g})$ & $30.4 \pm 27.5$ & - \\
\hline $\mathrm{P}$ & $3.0 \pm 51$ & $0.032 *$ \\
\hline $\mathrm{Al}$ & $61 \pm 56$ & $0.94^{*}$ \\
\hline $\mathrm{B}$ & $0.45 \pm 0.28$ & - \\
\hline $\mathrm{Cu}$ & $0.13 \pm 0.03$ & 8 \\
\hline $\mathrm{Fe}$ & $6.1 \pm 4.5$ & $0.37^{*}$ \\
\hline $\mathrm{Mn}$ & $9.0 \pm 3.0$ & $0.017^{*}$ \\
\hline $\mathrm{S}$ & $10.3 \pm 4.3$ & - \\
\hline $\mathrm{Zn}$ & $1.8 \pm 1.9$ & 4 \\
\hline $\mathrm{Cd}$ & $0.06 \pm 0.02$ & - \\
\hline $\mathrm{Cr}$ & $0.09 \pm 0.03$ & 8 \\
\hline $\mathrm{Ni}$ & $0.11 \pm 0.06$ & 5 \\
\hline $\mathrm{Pb}$ & $1.15 \pm 0.86$ & 3 \\
\hline $\mathrm{Si}$ & - & $4.08^{*}$ \\
\hline $\mathrm{Ti}$ & - & $0.050^{*}$ \\
\hline $\mathrm{Sc}$ & - & 2 \\
\hline $\mathrm{V}$ & - & 7 \\
\hline $\mathrm{Ba}$ & - & 13 \\
\hline $\mathrm{Rb}$ & - & 6 \\
\hline $\mathrm{Sr}$ & - & 231 \\
\hline $\mathrm{Zr}$ & - & 12 \\
\hline $\mathrm{Y}$ & - & 6 \\
\hline $\mathrm{Nb}$ & - & 4 \\
\hline
\end{tabular}


Table 1. Continued.

\begin{tabular}{lcc}
\hline \multirow{2}{*}{ Chemical } & \multicolumn{2}{c}{ Elemental Concentrations } \\
\cline { 2 - 3 } Features & Soil $($ mean $) \pm$ & \\
Measured & SD ppm $(\mathrm{mg} / \mathrm{kg})$ & Bedrock \\
\hline $\mathrm{Ga}$ & - & 2 \\
$\mathrm{La}$ & - & 5 \\
$\mathrm{Ce}$ & - & 8 \\
$\mathrm{Th}$ & - & 1 \\
$\mathrm{Nd}$ & - & 4 \\
$\mathrm{U}$ & - & 0 \\
$\mathrm{Ca} / \mathrm{Mg}$ & $22.7 \pm 17.2$ & - \\
$\mathrm{Na} / \mathrm{K}$ & $0.16 \pm 0.07$ & - \\
\hline
\end{tabular}

The most notable feature of the SCQP bryoflora is the absence of liverworts. Low liverwort diversity compared to moss diversity has been previously documented on calcareous substrates in northeastern North America (Cleavitt et al. 2009) and Europe (Kubesová and Chytrý 2005). The causes of this pattern are not well understood. There are calciphilic liverworts in this region (Crum 1991) - some of which were found by Briscoe et al. (2009) at a nearby serpentine outcrop. The moss flora of the SCQP includes a number of calciphillic species (Appendix 2), and the most abundant lichen, the muscicolous Scytinium lichenoides (= Leptogium lichenoides), is calcicolous as well. This lichen, along with the abundant Peltigera species at the SCQP, are cyanolichens, which are less tolerant of low $\mathrm{pH}$ than green algal lichens (Richardson and Cameron 2004). We speculate that the significantly higher proportion of calcicolous cryptogams versus vascular plants is due to the more direct exposure of bryophytes and lichens to limestone rock surfaces, whereas the interactions between vascular plants and the limestone rock are mediated by acidic soil.

The present study is an initial effort to investigate the biota of limestone soils in this area of coastal Maine. The vascular plant list, which was the primary objective of this study, can be regarded as comprehensive, whereas the bryophyte and (especially) lichen lists should be regarded primarily as documenting the most abundant and conspicuous species. A more complete bryophyte and lichen list for the SCQP and other nearby calcareous sites may be published in the future (A. C. Dibble et al., University of Maine, Orono, ME; unpubl. data). We recognize the limitations of the present study, the principal one being that only the immediate vicinity of the former quarrying operation was surveyed. A future expansion of this investigation should examine, in addition to the area already studied, the biota of 
non-quarried areas of limestone and neighboring non-calcareous lithologies (Osberg et al. 1985). This would allow us to better understand the natural reclamation of the SCQP and, more generally, the limestone flora of the Rockport area. An additional limitation was that we did not climb into the quarry pools to collect vascular plants, lichens, and bryophytes from the steep rock walls; a visual survey did not suggest that these walls were a particularly rich habitat, but a more detailed investigation could be attempted during future visits to this site.

The vascular plant survey at the SCQP limestone site adds another dimension to our understanding of edaphic ecology in Maine and New England. Though not currently recognized as a botanically unique site, the SCQP has been set aside as a nature preserve, and studies such as this survey provide land managers with information on the transition from highly disturbed sites to natural areas. At the former Simonton Corner Quarry, unlike numerous intentionally reclaimed quarries, this restoration was allowed to proceed spontaneously, a form of reclamation that was recently affirmed as being an effective restoration technique for limestone quarries (Tropek et al. 2010). The declaration of an abandoned quarry such as SCQP as a preserve indicates a shift in the perception of industrial sites from unredeemable scars to "experiments in creative conservation" (Grime 1972: 50).

ACKNOWLEDGments. The authors thank the Nature Conservancy and the Maine Coastal Mountains Land Trust, and especially Ian Stewart, Stewardship Director, and Scott Dickerson, Land Acquisition Coordinator, both of the Maine Coastal Mountains Land Trust, for permitting us to work at the Simonton Corner Quarry Preserve. This project was funded by a Maine Space Grant and a Garden Club of America Summer Environmental Studies Scholarship to the lead author. Dr. Robert Bertin and two anonymous reviewers provided comments which substantially improved this paper. We thank Cara Weber and Tasha Ball for their assistance in the field and general support for this project, Paul Excoffier for help in preparing the manuscript, Katie Jumper for her assistance in the field and identification of Peltigera specimens, and Glen Mittelhauser for his assistance with graminoid identifications. This paper is based on the B.A. thesis of the lead author.

\section{LITERATURE CITED}

Allen, B. 2005. Maine Mosses: Sphagnaceae-Timmiaceae. Mem. New York Bot. Gard. 93: 1-419. New York Botanical Garden Press, Bronx, NY. 
2014. Maine Mosses: Drummondiaceae-Polytrichaceae. Mem. New York Bot. Gard. 111: 1-607. New York Botanical Garden Press, Bronx, NY.

Atherton, I., S. D. S. Bosanquet, and M. Lawley, eds. 2010. Mosses and Liverworts of Britain and Ireland: A Field Guide. British Bryological Society, Plymouth, UK.

Bailey, S. W. 2013. Two fern species new to New Hampshire, with comments on the generation of calcareous-like habitat by base-poor rocks. Rhodora 115: 286-289.

- J. Hoy, And C. V. Cogbill. 2015. Vascular flora and geoecology of Mont de la Table, Gaspésie, Québec. Rhodora 117: 1-40.

Balter, H. and R. E. Loeb. 1983. Arboreal relationships on limestone and gneiss in northern New Jersey and southeastern New York. Bull. Torrey Bot. Club 110: 370-379.

Baskin, J. M. AND C. C. BASkin. 1974. Some aspects of the ecology of Ophioglossum engelmannii in the cedar glades of Kentucky and Tennessee. Amer. Fern J. 64: 65-73.

AND - 2004. History of the use of "cedar glades" and other descriptive terms for vegetation on rocky limestone soils in the central basin of Tennessee. Bot. Rev. 70: 403-424.

$\longrightarrow,-$, AND P. J. LAwLESS. 2007. Calcareous rock outcrop vegetation of eastern North America (exclusive of the Nashville Basin), with particular reference to the use of the term "Cedar Glades." Bot. Rev. 73: $303-325$.

Bastin, E. S. 1908. Rockland Folio, Maine. Geologic Atlas of the United States, Folio No. 158. US Geological Survey, Washington, DC.

BAtes, J. W. 1978. The influence of metal availability on the bryophyte and macrolichen vegetation of four rock types on Skye and Rhum. J. Ecol. 66: 457-482.

- 2008. Mineral nutrition and substratum ecology, pp. 299-356. In: B. Goffinet and A. J. Shaw, eds., Bryophyte Biology. Cambridge University Press, Cambridge, UK.

Brady, N. C. AND R. R. Weil. 1996. The Nature and Properties of Soils, 11th ed. Prentice-Hall Inc., Upper Saddle River, NJ.

Briscoe, L. R. E., T. B. Harris, E. Dannenberg, W. Broussard, F. C. Olday, AND N. RaJAKARUnA. 2009. Bryophytes of adjacent serpentine and granite outcrops on the Deer Isles, Maine, USA. Rhodora 111: 1-20.

Brumback, W. E. and J. Gerke. 2013. Flora Conservanda: New England 2012. The New England Plant Conservation Program (NEPCoP) list of plants in need of conservation. Rhodora 115: 313-408.

Brunton, D. F. 1986. Helleborine, Epipactis helleborine (Orchidaceae), in northern Ontario. Canad. Field-Naturalist 100: 127-130.

Catchpole, C. K. and C. F. Tydeman. 1975. Gravel pits as new wetland habitats for the conservation of breeding bird communities. Biol. Conservation 8: 47-59.

Cipollini, M. L., M. Strahl, N. S. Gorden, P. Tomlinson, and R. Ware. 2013. 
Vegetative survey of Martha's Meadow, an open limestone habitat in northwestern Georgia. S. E. Naturalist (Steuben) 12: 317-338.

Clarke, F. W. and H. S. Washington. 1924. The composition of the earth's crust. U.S. Geol. Survey Prof. Paper 127. US Government Printing Office, Washington, DC.

Cleavitt, N. L., S. A. Williams, and N. G. Slack. 2009. Relationship of bryophyte occurrence to rock type in upstate New York and coastal Maine. N. E. Naturalist 16: 67-84.

Crompton, C. W., A. E. Stahevitch, and W. A. Wojtas. 1990. Morphometric studies of the Euphorbia esula group (Euphorbiaceae) in North America. Canad. J. Bot. 68: 1978-1988.

Crow, S. E. And S. Ware. 2009. Soil type tolerance in rock outcrop plant communities: Satureja arkansana (Nutt.) Briq. (Lamiaceae) in the Ozarks. J. Torrey Bot. Soc. 136: 363-368.

Crum, H. A. 1991. Liverworts and Hornworts of Southern Michigan. University of Michigan Herbarium, Ann Arbor, MI.

Davis, B. N. K. 1976. Wildlife, urbanization and industry. Biol. Conservation 10: 249-291.

- 1979. Chalk and limestone quarries as wildlife habitats. Mineral. Environm. 1: 48-56.

- 1982. Regional variation in limestone quarries, pp. 12-19. In: B. N. K. Davis, ed., Ecology of Quarries. Institute of Terrestrial Ecology, Cambridge, UK.

, K. M. Lakhani, M. C. Brown, and D. G. Park. 1985. Early seral communities in a limestone quarry: An experimental study of treatment effects on cover and richness of vegetation. J. Appl. Ecol. 22: 473-490.

Department of Environment. 1976. Waste of waste land: The reclamation of derelict land and the prevention of dereliction in the United Kingdom. U.N. Habitat Conference, Vancouver, BC, Canada.

Dyke, A. S., J. T. Andrews, P. U. Clark, J. H. England, G. H. Miller, J. Shaw, and J. J. Veillette. 2002. The Laurentide and Innuitian ice sheets during the last glacial maximum. Quatern. Sci. Rev. 21: 9-31.

Fernald, M. L. AND K. M. Wiegand. 1910. A summer's botanizing in eastern Maine and western New Brunswick. Part 1. General notes on the summer trip. Rhodora 12: 101-121.

Finch, G. E. And G. F. Howe. 1930. The lime industry at Rockland, Maine. Econ. Geogr. 6: 389-397.

Foote, K. G. 1966. The vegetation of lichens and bryophytes on limestone outcrops in the driftless area of Wisconsin. Bryologist 69: 265-292.

Gandhi, K. N. 2016. Staghorn sumac: Rhus typhina or R. hirta (Anacardiaceae). Rhodora 118: 232-234.

Gilbert, O. L., B. W. Fox, And O. W. Purvis. 1982. The lichen flora of a highlevel limestone epidiorite outcrop in the Ben Alder range, Scotland. Lichenologist 14: 165-174.

Grime, J. P. 1972. The creative approach to nature conservation, pp. 47-54. In: 
F. J. Ebling and G. W. Heath, eds., The Future of Man. Academic Press, London, UK.

GrindLe, R. L. 1971. Quarry and kiln: The story of Maine's lime industry. The Courier-Gazette, Inc., Rockland, ME.

Haines, A. 2011. Flora Novae Angliae: A Manual for the Identification of Native and Naturalized Higher Vascular Plants of New England. Yale University Press, New Haven, CT.

Hattaway, R. A. 1980. The calciphilous bryophytes of three limestone sinks in eastern Tennessee. Bryologist 83: 161-169.

He, H. and L. Zhang. 2010. Polystichum kungianum, sp. nov. (sect. Mastigopteris, Dryopteridaceae) from Chongqing, China. Bot. Stud. 51: 395-401.

Hepler, P. K. 2005. Calcium: A central regulator of plant growth and development. Pl. Cell 17: 2142-2155.

Hill, S. R. 1992. Calciphiles and calcareous habitats of South Carolina. Castanea 75: 25-33.

Hinds, J. W. And P. L. Hinds. 2007. The Macrolichens of New England. Mem. New York Bot. Gard. 96: 1-584.

Hodgson, J. G. 1982. The botanical interest and value of quarries, pp. 3-11. In: B. N. K. Davis, ed., Ecology of Quarries: The Importance of Natural Vegetation. Institute of Terrestrial Ecology, Cambridge, UK.

Humphries, R. N. 1977. The development of vegetation in limestone quarries. Transactions Inst. Quarrying: Quarry Managem. Prod. 4: 43-47.

Ireland, R. R. and G. Bellolio-Trucco. 1987. Illustrated Guide to Some Hornworts, Liverworts, and Mosses of Eastern Canada. National Museums of Canada, National Museum of Natural Sciences, Ottawa, ON, Canada.

Johnson, D. M., P. R. Hooper, And R. M. Conrey. 1999. XRF analysis of rocks and minerals for major and trace elements on a single low dilution Li-tetraborate fused bead. Advances XRay Analysis 41: 843-867.

Johnson, M. S., P. D. Putwain, and R. J. Holliday. 1978. Wildlife conservation value of derelict metalliferous mine workings in Wales. Biol. Conservation 14: 131-148.

Kartesz, J. T. and The Biota of North America Program (BONAP). 2015. North American Plant Atlas. Chapel Hill, NC. [maps generated from Kartesz 2015. Floristic Synthesis of North America, Version 1.0. Biota of North America Program (BONAP). (in press)]. Website (http://bonap.net/ napa) last updated 12/15/2014.

Kay, K. M., K. L. Ward, L. R. Watt, and D. W. Schemske. 2011. Plant Speciation, pp. 71-96. In: S. P. Harrison and N. Rajakaruna, eds., Serpentine: Evolution and Ecology in a Model System. University of California Press, Berkeley, CA.

Kruckeberg, A. R. 2002. Geology and Plant Life: The Effects of Landforms and Rock Type on Plants. University of Washington Press, Seattle, WA.

KubesovÁ, S. And M. Chytrý. 2005. Diversity of bryophytes on treeless cliffs 
and talus slopes in a forested central European landscape. J. Bryol. 27: 3546.

Kuehn, D. M. C. And D. J. Leopold. 1993. Habitat characteristics associated with Phyllitis scolopendrium (L.) Newm. var. americana Fern. (Aspleniaceae) in Central New York. Bull. Torrey Bot. Club 120: 310-318.

Lawless, P. J., J. M. Baskin, And C. C. Baskin. 2006. Xeric limestone prairies of eastern United States: Review and synthesis. Bot. Rev. 72: 235-272.

LeE, J. A. 1998. The calcicole-calcifuge problem revisited. Advances Bot. Res. 29: $1-30$.

Long, C. A. E. 1921. Some rare plants from Knox County, Maine. Rhodora 23: 198-199.

MacLachlan, C. C., D. R. Hoch, and P. G. Merriman. 2006. Rockland Area Lime Industries. Arcadia Publishing, Charleston, SC.

Mansfield, M., N. Pope, G. Mittelehauser, and N. Rajakaruna. 2014. Diversity and soil-tissue elemental relations of vascular plants of Callahan Mine, Brooksville, Maine, USA. Rhodora 116: 283-322.

Mersereau, D. And A. DiTommaso. 2003. The biology of Canadian weeds. 121. Galium mollugo L. Canad. J. Pl. Sci. 83: 453-466.

New England Wildflower Society. 2015. Go Botany 2.2. New England Wild Flower Society, Framingham, MA. Website (http://gobotany. newenglandwild.org/). Accessed 9 May 2015.

O'Dell, R. E. 2014. Conservation and restoration of chemically extreme edaphic endemic flora in the western US, pp. 313-364. In: N. Rajakaruna, R. S. Boyd, and T. B. Harris, eds., Plant Ecology and Evolution in Harsh Environments. Nova Science Publishers, Inc., Hauppauge, NY.

- And V. P. Claassen. 2009. Serpentine revegetation: A review. N. E. Naturalist 16: 253-271.

- AND N. Rajakaruna. 2011. Intraspecific variation, adaptation, and evolution, pp. 97-137. In: S. P. Harrison and N. Rajakaruna, eds., Serpentine: Evolution and Ecology in a Model System. University of California Press, Berkeley, CA.

Osberg, P. H., A. M. Hussey II, And G. M. Boone, eds. 1985. Bedrock geologic map of Maine. Color map, scale 1:500,000. Maine Geological Survey, Augusta, ME.

Pope, N., T. B. Harris, and N. Rajakaruna. 2010. Vascular plants of adjacent serpentine and granite outcrops on the Deer Isles, Maine, U.S.A. Rhodora 112: 105-141.

Rajakaruna, N. 2004. The edaphic factor in the origin of species. Int. Geol. Rev. 46: 471-478.

- AND R. S. Boyd. 2008. The edaphic factor, pp. 1201-1207. In: S. E. Jorgenson and B. Fath, eds., The Encyclopedia of Ecology, Vol. 2. Elsevier, Oxford, UK.

Ratcliffe, D. A. 1974. Ecological effects of mineral exploitation in the United Kingdom and their significance to nature conservation. Proc. Roy. Soc. London, Ser. B, Biol. Sci. 339: 355-372. 
RAY, J. 1660. Ray's Flora of Cambridgeshire. 2nd revis. edition June 1975 by A. H. Ewen and C. T. Prime, eds. Wheldon and Wesley, Hitchens, UK.

ReINKING, M. F. 1979. A floristic analysis of two abandoned limestone quarries on Kelley's Island, Erie County, Ohio. M.S. thesis, The Ohio State University, Columbus, $\mathrm{OH}$.

Richardson, D. H. S. And R. P. Cameron. 2004. Cyanolichens: Their response to pollution and possible management strategies for their conservation in northeastern North America. N. E. Naturalist 11: 1-22.

Robinson, R. 1907. History of Camden and Rockport, Maine. Camden Publishing Company, Camden, ME.

Ross, J. J. 1970. A vascular flora of the limestone quarry on the Marblehead Peninsula, Ottawa County, Ohio. M.S. thesis, Ohio State University, Columbus, $\mathrm{OH}$.

Thompson, R. L., J. R. Aвbott, And A. E. Shupe. 2005. Vascular flora from five plant habitats of an abandoned limestone quarry in Clark County, Kentucky. J. Kentucky Acad. Sci. 66: 24-34.

- And S. R. GReEn. 2010. Vascular plants of an abandoned limestone quarry in Garrard County, Kentucky. Castanea 75: 245-258.

AND L. E. McKinney. 2006. Vascular flora and plant habitats of an abandoned limestone quarry at Center Hill Dam, DeKalb County, Tennessee. Castanea 71: 54-64.

Tropek, R., T. Kadlec, P. Karesova, L. Spitzer, P. Kocarek, I. Malenovsky, P. Banar, I. H. Tuf, M. Hejda, and M. Konvicka. 2010. Spontaneous succession in limestone quarries as an effective restoration tool for endangered arthropods and plants. J. Appl. Ecol. 47: 139-147.

Turekian, K. K. and K. H. Wedepohl. 1961. Distribution of the elements in some major units of the Earth's crust. Bull. Geol. Soc. Amer. 72: 175-192.

Tyler, G. AND T. Olsson. 2001. Plant uptake of major and minor mineral elements as influenced by soil acidity and liming. Pl. \& Soil 230: 307-321.

Usher, M. B. 1978. Natural communities of plants and animals in disused quarries. J. Environm. Managem. 8: 223-236.

Webb, D. A., And M. J. P. Scannell. 1983. Flora of Connemara and the Burren. Cambridge University Press, Cambridge, UK.

Wheater, C. P. AND W. R. Cullen. 1997. The flora and invertebrate fauna of abandoned limestone quarries in Derbyshire, United Kingdom. Restorat. Ecol. 5: 77-84.

White, P. J. And M. R. Broadley. 2003. Calcium in plants. Ann. Bot. 92: 487511.

Yarranton, G. A. And W. G. E. Green. 1966. The distributional pattern of crustose lichens on limestone cliffs at Rattlesnake Point, Ontario. Bryologist 69: 450-461.

Yesilyurt, J. C. And H. Schneider. 2010. The new fern genus Calciphilopteris (Pteridaceae). Phytotaxa 7: 52-59. 


\section{APPENDIX 1}

Vascular plants collected at the Simonton Corner Quarry Preserve. Nat. (Nativity) denotes species native to Maine ( $\mathrm{Y}=$ yes; $\mathrm{N}=$ no). Nomenclature and native/nonnative status are from the New England Wildflower Society (2015), except for Rhus typhina L., which is the correct name for staghorn sumac (Gandhi 2016). Species marked with an asterisk $(*)$ were confirmed in the field by the senior author and are not vouchered; all other specimens are vouchered at HCOA. The three columns under the heading Cover refer to the plant cover data collected in 30 plots of $5 \times 5 \mathrm{~m}$ each. Freq. $=$ the number of plots in which the species was found. Avg. $\%=$ the average percent cover over the plots where the species was present, and SD $\%=$ the standard deviation in cover between plots where the species was present. Cover was not recorded for trees.

\begin{tabular}{|c|c|c|c|c|c|}
\hline \multirow[b]{2}{*}{ Family } & \multirow[b]{2}{*}{ Species } & \multirow[b]{2}{*}{ Nat. } & \multicolumn{3}{|c|}{ Cover } \\
\hline & & & Freq. & $\begin{array}{c}\text { Avg. } \\
\%\end{array}$ & $\begin{array}{l}\text { SD } \\
\% \\
\end{array}$ \\
\hline \multirow[t]{2}{*}{ ADOXACEAE } & Viburnum acerifolium $\mathrm{L}$. & Y & 15 & 1 & 1 \\
\hline & Viburnum dentatum $\mathrm{L}$. & $\mathrm{Y}$ & 5 & $<1$ & $<1$ \\
\hline \multirow[t]{2}{*}{ ANACARDIACEAE } & Rhus typhina $\mathrm{L} . *$ & $\mathrm{Y}$ & 2 & 2 & 1 \\
\hline & $\begin{array}{l}\text { Toxicodendron radicans }(\mathrm{L} .) \\
\text { Kuntze }\end{array}$ & $\mathrm{Y}$ & 10 & 17 & 18 \\
\hline APIACEAE & Daucus carota L. & $\mathrm{N}$ & 0 & - & - \\
\hline \multirow[t]{2}{*}{ APOCYNACEAE } & Apocynum sp. & Y & 1 & $<1$ & - \\
\hline & Asclepias syriaca $\mathrm{L}$. & $\mathrm{Y}$ & 0 & - & - \\
\hline ARACEAE & $\begin{array}{l}\text { Arisaema triphyllum (L.) Schott } \\
\text { subsp. triphyllum }\end{array}$ & Y & 0 & - & - \\
\hline ASPARAGACEAE & Asparagus officinalis $\mathrm{L}$. & $\mathrm{N}$ & 1 & $<1$ & - \\
\hline \multirow[t]{14}{*}{ ASTERACEAE } & $\begin{array}{l}\text { Achillea millefolium L. subsp. } \\
\text { lanulosa (Nutt.) Piper * }\end{array}$ & $\mathrm{Y}$ & 1 & $<1$ & - \\
\hline & Bidens cernua $\mathrm{L}$. & $\mathrm{Y}$ & 0 & - & - \\
\hline & Cichorium intybus $\mathrm{L}$. & $\mathrm{N}$ & 0 & - & - \\
\hline & Cirsium vulgare (Savi) Ten. & $\mathrm{N}$ & 0 & - & - \\
\hline & $\begin{array}{l}\text { Doellingeria umbellata (Mill.) } \\
\text { Nees var. umbellata }\end{array}$ & $\mathrm{Y}$ & 0 & - & - \\
\hline & $\begin{array}{l}\text { Erigeron strigosus var. } \\
\text { septentrionalis (Fernald \& } \\
\text { Wiegand) Fernald }\end{array}$ & Y & 2 & 1 & 1 \\
\hline & Eurybia macrophylla (L.) Cass. & Y & 1 & 2 & - \\
\hline & Euthamia graminifolia (L.) Nutt. & Y & 1 & 1 & - \\
\hline & Hieracium piloselloides Vill. & $\mathrm{N}$ & 19 & 3 & 2 \\
\hline & Leucanthemum vulgare Lam. & $\mathrm{N}$ & 1 & 1 & - \\
\hline & $\begin{array}{l}\text { Rudbeckia hirta } \mathrm{L} \text {. var. } \\
\text { pulcherrima }\end{array}$ & $\mathrm{N}$ & 0 & - & - \\
\hline & $\begin{array}{l}\text { Solidago canadensis L. var. } \\
\quad \text { canadensis }\end{array}$ & $\mathrm{Y}$ & 2 & 5 & 6 \\
\hline & Solidago flexicaulis $\mathrm{L}$. & $\mathrm{Y}$ & 7 & 8 & 11 \\
\hline & Solidago gigantea Aiton & $\mathrm{Y}$ & 2 & $<1$ & $<1$ \\
\hline
\end{tabular}


APPENDIX 1. Continued.

\begin{tabular}{|c|c|c|c|c|c|}
\hline \multirow[b]{2}{*}{ Family } & \multirow[b]{2}{*}{ Species } & \multirow[b]{2}{*}{ Nat. } & \multicolumn{3}{|c|}{ Cover } \\
\hline & & & Freq. & $\begin{array}{l}\text { Avg. } \\
\%\end{array}$ & $\begin{array}{c}\mathrm{SD} \\
\%\end{array}$ \\
\hline & Solidago juncea Aiton & Y & 1 & $<1$ & - \\
\hline & $\begin{array}{l}\text { Solidago rugosa P. Mill. subsp. } \\
\quad \text { rugosa }\end{array}$ & $\mathrm{Y}$ & 2 & $<1$ & $<1$ \\
\hline & $\begin{array}{l}\text { Symphyotrichum ericoides (L.) } \\
\text { G.L. Nesom var. ericoides }\end{array}$ & $\mathrm{Y}$ & 0 & - & - \\
\hline & $\begin{array}{l}\text { Symphyotrichum lateriflorum (L.) } \\
\text { Á. \& D. Löve }\end{array}$ & $\mathrm{Y}$ & 14 & $<1$ & $<1$ \\
\hline & $\begin{array}{l}\text { Symphyotrichum novae-angliae } \\
\text { (L.) G.L. Nesom }\end{array}$ & Y & 0 & - & - \\
\hline & Tanacetum vulgare $\mathrm{L}$. & $\mathrm{N}$ & 1 & $<1$ & - \\
\hline & $\begin{array}{l}\text { Taraxacum officinale F.H. Weber } \\
\text { ex Wigg. }\end{array}$ & $\mathrm{N}$ & 27 & 1 & 1 \\
\hline BERBERIDACEAE & Berberis thunbergii DC. * & $\mathrm{N}$ & 10 & $<1$ & $<1$ \\
\hline \multirow[t]{4}{*}{ BETULACEAE } & $\begin{array}{l}\text { Betula papyrifera Marshall var. } \\
\text { papyrifera } *\end{array}$ & $\mathrm{Y}$ & 5 & - & - \\
\hline & Betula populifolia Marshall & Y & 2 & - & - \\
\hline & $\begin{array}{l}\text { Corylus cornuta Marshall subsp. } \\
\text { cornuta }\end{array}$ & $\mathrm{Y}$ & 3 & 2 & 3 \\
\hline & $\begin{array}{l}\text { Ostrya virginiana (P. Mill.) K. } \\
\text { Koch }\end{array}$ & Y & 5 & - & - \\
\hline BORAGINACEAE & Myosotis arvensis (L.) Hill & $\mathrm{N}$ & 1 & $<1$ & - \\
\hline BRASSICACEAE & Hesperis matronalis $\mathrm{L}$. & $\mathrm{N}$ & 0 & - & - \\
\hline \multirow[t]{3}{*}{ CAPRIFOLIACEAE } & Diervilla lonicera P. Mill. * & $\mathrm{Y}$ & 1 & 9 & - \\
\hline & Lonicera morrowii Gray & $\mathrm{N}$ & 16 & 3 & 4 \\
\hline & Valeriana officinalis L. & $\mathrm{N}$ & 6 & 1 & 1 \\
\hline \multirow[t]{2}{*}{ CARYOPHYLLACEAE } & Moehringia lateriflora (L.) Fenzl & $\mathrm{Y}$ & 0 & - & - \\
\hline & Stellaria graminea $\mathrm{L}$. & $\mathrm{N}$ & 0 & - & - \\
\hline CELASTRACEAE & Celastrus orbiculatus Thunb. * & $\mathrm{N}$ & 5 & 1 & 1 \\
\hline \multirow[t]{2}{*}{ CORNACEAE } & Swida alternifolia (L.f.) Small & $\mathrm{Y}$ & 21 & 6 & 5 \\
\hline & Swida rugosa (Lam.) Rydb. & $\mathrm{Y}$ & 2 & 14 & 3 \\
\hline CUPRESSACEAE & $\begin{array}{l}\text { Juniperus communis L. var. } \\
\quad \text { depressa Pursh * }\end{array}$ & Y & 13 & 11 & 15 \\
\hline \multirow[t]{3}{*}{ CYPERACEAE } & $\begin{array}{l}\text { Carex brunnescens var. } \\
\text { brunnescens (Pers.) Poir. }\end{array}$ & $\mathrm{Y}$ & 9 & 4 & 5 \\
\hline & Carex interior Bailey & $\mathrm{Y}$ & 0 & - & - \\
\hline & Carex pallescens L. & $\mathrm{Y}$ & 5 & $<1$ & $<1$ \\
\hline \multirow[t]{2}{*}{ DRYOPTERIDACEAE } & $\begin{array}{l}\text { Dryopteris intermedia (Willd.) A. } \\
\text { Gray }\end{array}$ & $\mathrm{Y}$ & 1 & $<1$ & - \\
\hline & $\begin{array}{l}\text { Polystichum acrostichoides } \\
\text { (Michx.) Schott* }\end{array}$ & Y & 0 & - & - \\
\hline EQUISETACEAE & Equisetum arvense $\mathrm{L}$. & $\mathrm{Y}$ & 1 & $<1$ & - \\
\hline ERICACEAE & Hypopitys monotropa Crantz. & Y & 5 & 1 & 2 \\
\hline EUPHORBIACEAE & Euphorbia cyparissias $\mathrm{L}$. & $\mathrm{N}$ & 0 & - & - \\
\hline
\end{tabular}


APPENDIX 1. Continued.

\begin{tabular}{|c|c|c|c|c|c|}
\hline \multirow[b]{2}{*}{ Family } & \multirow[b]{2}{*}{ Species } & \multirow[b]{2}{*}{ Nat. } & \multicolumn{3}{|c|}{ Cover } \\
\hline & & & Freq. & $\underset{\%}{\text { Avg. }}$ & $\begin{array}{c}\text { SD } \\
\%\end{array}$ \\
\hline \multirow[t]{5}{*}{ FABACEAE } & Medicago lupulina $\mathrm{L}$. & $\mathrm{N}$ & 0 & - & - \\
\hline & Melilotus albus Medik. & $\mathrm{N}$ & 4 & 1 & 1 \\
\hline & Melilotus officinalis (L.) Pall. & $\mathrm{N}$ & 1 & 3 & - \\
\hline & Securigera varia (L.) Lassen & $\mathrm{N}$ & 0 & - & - \\
\hline & Vicia villosa subsp. villosa Roth & $\mathrm{N}$ & 3 & 1 & 1 \\
\hline \multirow[t]{2}{*}{ FAGACEAE } & Fagus grandifolia Ehrh. & Y & 9 & - & - \\
\hline & Quercus rubra L. * & $\mathrm{Y}$ & 14 & - & - \\
\hline GERANIACEAE & Geranium robertianum L. & $\mathrm{Y}$ & 2 & 22 & 25 \\
\hline HYPERICACEAE & $\begin{array}{l}\text { Hypericum perforatum subsp. } \\
\text { perforatum } \mathrm{L} \text {. }\end{array}$ & $\mathrm{N}$ & 0 & - & - \\
\hline IRIDACEAE & $\begin{array}{l}\text { Sisyrinchium angustifolium } \mathrm{P} \text {. } \\
\text { Mill. }\end{array}$ & $\mathrm{Y}$ & 0 & - & - \\
\hline JUNCACEAE & Juncus articulatus L. & Y & 0 & - & - \\
\hline LAMIACEAE & Galeopsis bifida Boenn. & $\mathrm{N}$ & 2 & 1 & $<1$ \\
\hline LYTHRACEAE & Lythrum salicaria $\mathrm{L}$. & $\mathrm{N}$ & 0 & - & - \\
\hline MELANTHIACEAE & Trillium erectum $\mathrm{L}$. & $\mathrm{Y}$ & 2 & 1 & $<1$ \\
\hline MYRICACEAE & $\begin{array}{l}\text { Comptonia peregrina (L.) J.M. } \\
\text { Coult. }\end{array}$ & $\mathrm{Y}$ & 1 & $<1$ & - \\
\hline MYRSINACEAE & $\begin{array}{l}\text { Lysimachia borealis (Raf.) U. } \\
\text { Manns \& A. Anderb. }\end{array}$ & $\mathrm{Y}$ & 1 & $<1$ & - \\
\hline OLEACEAE & Fraxinus americana $\mathrm{L}$. & Y & 28 & - & - \\
\hline ONOCLEACEAE & Onoclea sensibilis L. & Y & 2 & 13 & 18 \\
\hline ORCHIDACEAE & Epipactis helleborine (L.) Crantz & $\mathrm{N}$ & 8 & $<1$ & $<1$ \\
\hline \multirow[t]{2}{*}{ PINACEAE } & Abies balsamea (L.) P. Mill. & $\mathrm{Y}$ & 6 & - & - \\
\hline & Pinus strobus L. & $\mathrm{Y}$ & 24 & - & - \\
\hline \multirow[t]{3}{*}{ PLANTAGinaCeAe } & Plantago major L. & $\mathrm{N}$ & 1 & $<1$ & - \\
\hline & Veronica officinalis $\mathrm{L}$. & $\mathrm{N}$ & 5 & 1 & 1 \\
\hline & Veronica scutellata $\mathrm{L}$. & $\mathrm{Y}$ & 4 & 5 & 5 \\
\hline \multirow[t]{8}{*}{ POACEAE } & Agrostis gigantea Roth & $\mathrm{N}$ & 1 & 1 & - \\
\hline & Dactylis glomerata $\mathrm{L}$. & $\mathrm{N}$ & 0 & - & - \\
\hline & $\begin{array}{l}\text { Danthonia spicata (L.) P. Beauv. } \\
\text { ex Roemer \& J.A. Schultes }\end{array}$ & $\mathrm{Y}$ & 2 & 1 & 1 \\
\hline & $\begin{array}{l}\text { Festuca trachyphylla (Hack.) } \\
\text { Krajina }\end{array}$ & $\mathrm{N}$ & 6 & 4 & 5 \\
\hline & Phleum pratense $\mathrm{L}$. & $\mathrm{N}$ & 4 & 7 & 9 \\
\hline & Poa compressa $\mathrm{L}$. & $\mathrm{N}$ & 8 & 2 & 4 \\
\hline & $\begin{array}{l}\text { Poa pratensis L. subsp. } \\
\text { angustifolia }\end{array}$ & $\mathrm{N}$ & 2 & 3 & 3 \\
\hline & Poa pratensis L. subsp. pratensis & $\mathrm{N}$ & 0 & - & - \\
\hline \multirow[t]{3}{*}{ RANUNCULACEAE } & Actaea pachypoda Elliott & $\mathrm{Y}$ & 3 & 2 & 1 \\
\hline & Actaea rubra (Aiton) Willd. & $\mathrm{Y}$ & 0 & - & - \\
\hline & $\begin{array}{l}\text { Anemone quinquefolia } \mathrm{L} \text {. var. } \\
\text { quinquefolia }\end{array}$ & Y & 0 & - & - \\
\hline
\end{tabular}


APPENDIX 1. Continued.

\begin{tabular}{|c|c|c|c|c|c|}
\hline \multirow[b]{2}{*}{ Family } & \multirow[b]{2}{*}{ Species } & \multirow[b]{2}{*}{ Nat. } & \multicolumn{3}{|c|}{ Cover } \\
\hline & & & Freq. & $\begin{array}{c}\text { Avg. } \\
\%\end{array}$ & $\begin{array}{l}\text { SD } \\
\% \\
\end{array}$ \\
\hline & Ranunculus acris L. & $\mathrm{N}$ & 10 & $<1$ & $<1$ \\
\hline \multirow[t]{2}{*}{ RHAMNACEAE } & Frangula alnus $\mathrm{P}$. Mill. & $\mathrm{N}$ & 13 & 1 & 2 \\
\hline & Rhamnus cathartica $\mathrm{L}$. & $\mathrm{N}$ & 0 & - & - \\
\hline \multirow[t]{10}{*}{ ROSACEAE } & Amelanchier sp. & $\mathrm{Y}$ & 2 & 1 & $<1$ \\
\hline & Crataegus sp. & $\mathrm{Y}$ & 0 & - & - \\
\hline & $\begin{array}{l}\text { Fragaria virginiana Duchesne } \\
\text { subsp. virginiana } *\end{array}$ & $\mathrm{Y}$ & 8 & 1 & 1 \\
\hline & Malus pumila Mill. * & $\mathrm{N}$ & 2 & - & - \\
\hline & Potentilla canadensis $\mathrm{L}$. & $\mathrm{Y}$ & 2 & 1 & 1 \\
\hline & $\begin{array}{l}\text { Prunus serotina Ehrh. var. } \\
\text { serotina } *\end{array}$ & $\mathrm{Y}$ & 17 & 2 & 2 \\
\hline & $\begin{array}{l}\text { Prunus virginiana } \mathrm{L} . \text { var. } \\
\text { virginiana }\end{array}$ & $\mathrm{Y}$ & 27 & 7 & 8 \\
\hline & Rosa multiflora Thunb. ex Murr. * & $\mathrm{N}$ & 4 & 1 & 1 \\
\hline & $\begin{array}{l}\text { Rubus idaeus L. subsp. strigosus } \\
\text { (Michx.) Focke }\end{array}$ & $\mathrm{Y}$ & 5 & 9 & 5 \\
\hline & Spiraea alba Du Roi & $\mathrm{Y}$ & 1 & $<1$ & - \\
\hline RUBIACEAE & Galium mollugo L. & $\mathrm{N}$ & 16 & 1 & 2 \\
\hline \multirow[t]{3}{*}{ RUSCACEAE } & Convallaria majalis L. & $\mathrm{N}$ & 1 & 14 & - \\
\hline & Maianthemum canadense Desf. & Y & 16 & 2 & 2 \\
\hline & $\begin{array}{l}\text { Maianthemum racemosum } \mathrm{L} \text {. } \\
\text { subsp. racemosum }\end{array}$ & $\mathrm{Y}$ & 6 & $<1$ & $<1$ \\
\hline \multirow[t]{2}{*}{ SALICACEAE } & Populus tremuloides Michx. * & $\mathrm{Y}$ & 7 & - & - \\
\hline & Salix cf. bebbiana Sarg. & $\mathrm{Y}$ & 1 & 1 & - \\
\hline \multirow[t]{2}{*}{ SAPINDACEAE } & Acer ginnala Maxim. & $\mathrm{N}$ & 1 & - & - \\
\hline & $\begin{array}{l}\text { Acer saccharum Marshall var. } \\
\text { saccharum }\end{array}$ & $\mathrm{Y}$ & 15 & - & - \\
\hline SAXIFRAGACEAE & $\begin{array}{l}\text { Tiarella cordifolia L. var. } \\
\text { cordifolia }\end{array}$ & Y & 3 & 2 & 3 \\
\hline SOLANACEAE & Solanum dulcamara $\mathrm{L}$. & $\mathrm{N}$ & 6 & $<1$ & $<1$ \\
\hline ULMACEAE & Ulmus americana $\mathrm{L}$. & $\mathrm{Y}$ & 3 & - & - \\
\hline VITACEAE & $\begin{array}{l}\text { Parthenocissus quinquefolia (L.) } \\
\text { Planch. * }\end{array}$ & $\mathrm{Y}$ & 8 & 2 & 3 \\
\hline WOODSIACEAE & $\begin{array}{l}\text { Athyrium angustum (Willd.) C. } \\
\text { Presl }\end{array}$ & $\mathrm{Y}$ & 1 & 9 & - \\
\hline
\end{tabular}


APPENDIX 2

Bryophytes species documented at Simonton Corner Quarry Preserve. Calcicolous preference according to Allen $(2005,2014)$ and Atherton et al. (2010).

\begin{tabular}{|c|c|c|}
\hline Family & Species & Calcicole \\
\hline AMBLYSTEGIACEAE & $\begin{array}{l}\text { Calliergon cordifolium (Hedw.) Kindb. } \\
\text { Campylium chrysophyllum (Brid.) J. Lange } \\
\text { Hygroamblystegium tenax var. spinifolium } \\
\text { (Schimp.) Jenn. }\end{array}$ & $\begin{array}{l}\text { No } \\
\text { Yes }\end{array}$ \\
\hline ANOMODONTACEAE & $\begin{array}{l}\text { Anomodon attenuatus (Hedw.) Hüb. } \\
\text { Anomodon rostratus (Hedw.) Schimp. }\end{array}$ & $\begin{array}{l}\text { Yes } \\
\text { Yes }\end{array}$ \\
\hline AULACOMNIACEAE & Aulacomnium palustre (Hedw.) Schwägr. & No \\
\hline BRACHYTHECIACEAE & $\begin{array}{l}\text { Brachythecium calcareum Kindb. } \\
\text { Brachythecium cf. rivulare Schimp. } \\
\text { Brachythecium rutabulum (Hedw.) Schimp. in } \\
\text { B.S.G. } \\
\text { Steerecleus serrulatus (Hedw.) H. Rob. }\end{array}$ & $\begin{array}{l}\text { Yes } \\
\text { No }\end{array}$ \\
\hline ENCALYPTACEAE & Encalypta procera Bruch & Yes \\
\hline FISSIDENTACEAE & Fissidens dubius P. Beauv. & Yes \\
\hline HYLOCOMIACEAE & Rhytidiadelphus triquetrus (Hedw.) Warnst. & No \\
\hline HYPNACEAE & Hypnum cupressiforme Hedw. & No \\
\hline LESKEACEAE & Thuidium delicatulum (Hedw.) Schimp. & No \\
\hline ORTHOTRICHACEAE & Orthotrichum anomalum Hedw. & Yes \\
\hline PLAGIOMNIACEAE & Plagiomnium cuspidatum (Hedw.) T.J. Kop. & No \\
\hline POLYTRICHACEAE & $\begin{array}{l}\text { Atrichum crispulum Schimp ex Besch. } \\
\text { Atrichum undulatum (Hedw.) P. Beauv. } \\
\text { Polytrichum commune Hedw. }\end{array}$ & $\begin{array}{l}\text { No } \\
\text { No } \\
\text { No }\end{array}$ \\
\hline POTTIACEAE & Tortella tortuosa (Hedw.) Limpr. & Yes \\
\hline
\end{tabular}

APPENDIX 3

Lichen species documented at Simonton Corner Quarry Preserve. Calcicolous preference according to Hinds and Hinds (2007).

\begin{tabular}{|c|c|c|}
\hline Family & Species & Calcicole \\
\hline \multirow[t]{2}{*}{ CLADONIACEAE } & Cladonia fimbriata (L.) Fr. & No \\
\hline & Cladonia pyxidata (L.) Hoffm. & No \\
\hline COLLEMATACEAE & $\begin{array}{l}\text { Scytinium lichenoides (L.) Otálora, P.M. } \\
\text { Jørg. \& Wedin }\end{array}$ & Yes \\
\hline \multirow[t]{5}{*}{ PELTIGERACEAE } & Peltigera canina (L.) Willd. & No \\
\hline & Peltigera elisabethae Gyelnik & Yes \\
\hline & Peltigera horizontalis (Huds.) Baumg. & No \\
\hline & Peltigera lepidophora (Vain.) Bitter. & Yes \\
\hline & $\begin{array}{l}\text { Peltigera praetextata (Flörke ex Sommerf.) } \\
\text { Zopf }\end{array}$ & No \\
\hline
\end{tabular}

